\title{
The Gutian Invasion in the Middle East as a Possible Anthropogenic Trigger Factor in the Development of the 4.2 ky Event
}

\author{
Tomasz J. Szczęsny \\ Faculty of Political Science and International Studies, Nicolaus Copernicus University, Toruń, Poland \\ Email: tomjaszczesny@gmail.com
}

How to cite this paper: Szczęsny, T.J. (2019) The Gutian Invasion in the Middle East as a Possible Anthropogenic Trigger Factor in the Development of the $4.2 \mathrm{ky}$ Event. Open Journal of Ecology, 9, 336-359. https://doi.org/10.4236/oje.2019.99024

Received: August 6, 2019

Accepted: September 9, 2019

Published: September 12, 2019

Copyright ( 2019 by author(s) and Scientific Research Publishing Inc. This work is licensed under the Creative Commons Attribution International License (CC BY 4.0).

http://creativecommons.org/licenses/by/4.0/

\section{cC) (7) Open Access}

\begin{abstract}
It is commonly accepted that the current global warming is caused by humans, especially by anthropogenic emission of carbon dioxide. It is justifiably considered to be one of the biggest threats for life on the planet and human civilization. However, since millennia humans have been changing the climate locally and globally. Especially after the development of agriculture and animal husbandry people have been progressively increasing the albedo of the planet. The cooling of the climate that took place since the Neolithic Revolution and lasted until the onset of the Industrial Revolution corresponds better with the growth of human population than with any other factor. The current global warming threatens with drought, hunger, migrations and inundation of coastal areas. However, throughout the human history, it was the cooling that was related to drought and hunger. The cooling and drought that occurred about 4.2 thousand years ago (the 4.2 ky event) were the most severe. It resulted in the collapse of all Neolithic civilizations. Its reason is still not explained. This paper presents a hypothesis how people could unwillingly cause change in monsoons' strength and direction as well as global climate catastrophe that occurred 4.2 thousand years ago.
\end{abstract}

\section{Keywords}

4.2 ky Event, Global Warming, Monsoons, Global Cooling, Neolith

\section{Introduction}

The current global warming made us realize that humans are able to change the climate on a global scale. However, people have been changing the climate at least since the development of agriculture, since they learned how to grow crops and domesticate animals. The subsequent demographic explosion lasts until to- 
day. Its result is a destruction of natural forests and aridification of areas prone to desertification. Both these processes increase albedo of the planet resulting in a progressive cooling of the climate because increasing albedo increases the ratio of reflected solar radiation to absorbed solar radiation. This cooling was deteriorated by a retreat of the northern border of the boreal forest and changing it into tundra which further increased albedo and cooled the climate globally. The global cooling started about 6000 years ago and lasted until the onset of the industrial revolution. The cooling started with the Neolithic Revolution (due to rapid development of agriculture and animal husbandry) and was aggravated after discovery of Americas, due to concomitant technological progress which led to even more rapid growth of population [Figure 1]. Throughout the Northgrippian and Meghalayan Stages of the Holocene, the insolation of the northern hemisphere has been decreasing, mostly due to decreasing axial tilt. Nevertheless, the cooling, especially the severe cooling which occurred after the Middle Ages called the Little Ice Age (1570-1900), corresponds better with population size than with orbital forcing. The latter cold period was aggravated by the Maunder Minimum (1645-1715) but it started earlier and finished later than this minimal solar activity. The Little Ice Age was the most severe after the Maunder Minimum was over.

Also, since the development of animal husbandry and agriculture, the carbon dioxide concentration in the atmosphere has been growing: from about $260 \mathrm{ppm}$ in the middle of the Holocene to almost $280 \mathrm{ppm}$ at the onset of the industrial revolution [1]. This increase in the $\mathrm{CO}_{2}$ atmospheric concentration was a result of release into the atmosphere of the carbon which in the beginning and middle of the Holocene was accumulated in the lush vegetation, more fertile soils and peat bogs. Despite this growth of $\mathrm{CO}_{2}$ atmosphere concentration, the climate was progressively colder, until people reached for fossil fuels and released to the atmosphere the carbon which was accumulated throughout millions of years by photosynthesizing organisms. This proves that before the Industrial Era increasing

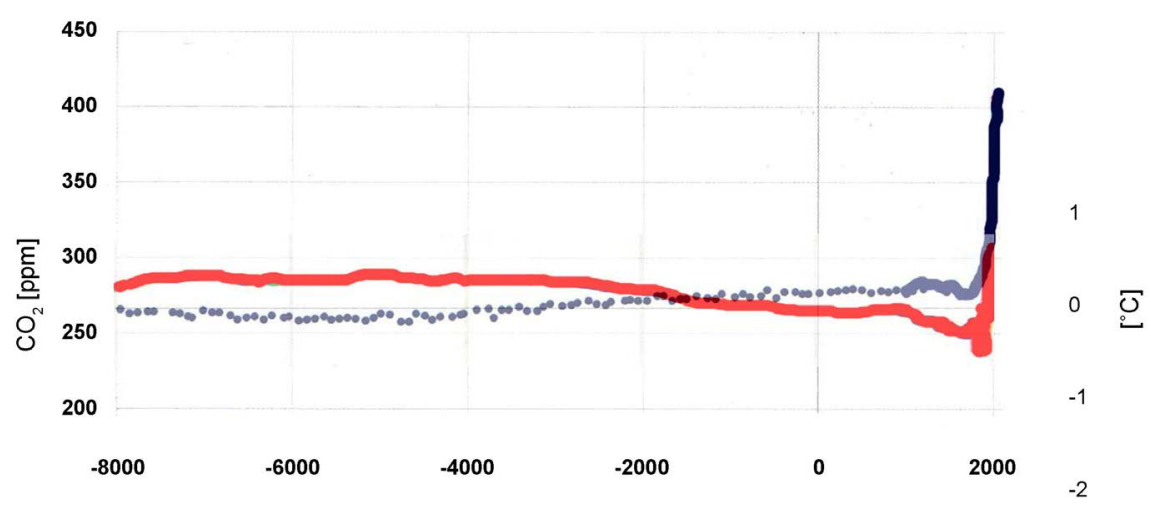

Figure 1. Mean global temperature and carbon dioxide atmosphere concentration during Northgrippian and Meghalayan stages of the Holocene. Note the rapid cooling related to rapid growth of population just before the Industrial Era, after the end of the Maunder Minimum. Red line shows the mean global temperature. 
albedo was a dominant factor influencing the global temperature, overwhelming the warming role of increasing $\mathrm{CO}_{2}$ in the atmosphere. Decreasing global temperature caused greater solubility of carbon dioxide in ocean water, without which the increase in carbon dioxide concentration in the atmosphere would have been even greater. The current $\mathrm{CO}_{2}$ concentration in the atmosphere is about $410 \mathrm{ppm}$ and results in elevation of the mean global temperature by about $1^{\circ} \mathrm{C}$. It is possible that the current global warming barely balances the global cooling caused by our predecessors.

The current global warming threatens with drought, hunger, migrations and inundation of coastal areas. But throughout the human history, it was the cooling that used to be combined with drought resulting in hunger, misery and epidemics. Some of these cold events were caused by volcanic eruptions which resulted in cold and dry conditions lasting even several years. For example, it is believed that volcanic eruption in Iceland triggered the French Revolution which created the French Republic. Among all cold events, throughout human history the cooling and drought called the $4.2 \mathrm{ky}$ event (because it happened about 4.2 thousand years ago) was the most severe. It resulted in the collapse of all Neolithic civilizations: the Old Kingdom in Egypt, the Akkadian Empire in Mesopotamia, urban Harappan civilization in India and Neolithic civilizations which thrived around the East China Plain. A number of smaller Neolithic civilizations, for example in Malta and Central Asia, also collapsed at the time. The $4.2 \mathrm{ky}$ event caused the shift of settlements and organization of most people living on the planet. It was the most severe along the Tropic of Cancer, where all Neolithic civilizations developed. The reason for this event is still unknown.

\section{Methods}

A review of literature was performed to analyze the possible impact of humans on the Earth's climate since the Neolith. It concentrates on the human impact on the planet's albedo, plant canopy and carbon dioxide concentration in the atmosphere. Data obtained from climatological, archeological and historical scientific publications were used to perform a cause-and-effect analysis of possible human impact on the course of prevalent humid winds on Earth: summer monsoons, the Walker circulation and Middle-Latitudes Westerlies.

\section{Results}

\section{The onset of human civilizations and their relationship with the climate}

In July 2018 the International Union of Geological Sciences proposed subdivision of the Holocene into three time intervals: Greenlandian Stage $(11,700$ through 8300 years ago), Northgrippian Stage (8300 through 4200 years ago) and Meghalayan Stage (4200 years ago until present) [2]. The boundaries between these three stages are marked with two periods of global cooling and drought. The first cold and dry period is called the 8.2 ky (kiloyear) event because it occurred about 8200 years ago (it lasted about 400 - 600 years), while the 
second one is called the $4.2 \mathrm{ky}$ event and lasted about 200 years. The first period was probably initiated or at least aggravated by the final discharge of Lake Agassiz to the Atlantic Ocean which increased the sea ice cover in the northern Atlantic, impaired the thermohaline circulation of this ocean and stopped the Gulf Stream, similarly like it happened during the Younger Dryas. It was accompanied by cold and dry conditions all over the world, especially in Europe [3] [4] [5]. It was followed by an increased sea level until about 7000 years ago, after extended sea ice was melted by a revived thermohaline circulation, mostly due to thermal expansion of water [6].

The reason of the $4.2 \mathrm{ky}$ event is not clear. Probably one of the reasons of its development was a lower solar activity that occurs every 1500 years, called Bond events. It is also hypothesized that it was influenced or aggravated by an increased albedo of areas north from the Tropic of Cancer due to extensive deforestation and aridification caused by rapidly growing human population [7] [8] [9] [10]. If so, the $4.2 \mathrm{ky}$ event could be called the first global climate catastrophe caused by humans and might be treated as the mark point of the beginning of the Anthropocene.

\section{The Greenlandian Stage (11,799 - 8300 years ago)}

At the beginning of the Holocene the mean global temperature was about $2{ }^{\circ} \mathrm{C}$ lower than today as a result of a high albedo of the remaining ice sheets. However, thanks to beneficial high insolation, until the end of the Greenlandian Stage all major ice sheets and glaciers from North America, Europe and Siberia retreated. Therefore the Earth's albedo was diminishing and the mean global temperature was growing. Except orbital forcing, several positive feedback mechanisms contributed to the global warming at the time, for example, increasing afforestation was responsible for decreasing Earth's albedo, too. Also, release of methane from the melting ice and permafrost increased the greenhouse effect. The warming was accompanied by the rise of sea level by about 35 meters in 2400 years ( $15 \mathrm{~mm}$ per year, that is five times faster than at the beginning of the current millennium), until 7000 years ago, when the coastline reached its contemporary borders. Thanks to increasing precipitation most of previous polar and tropical deserts covered with grass, shrubs and trees. Because of bigger axial tilt which reached its maximum about 10,900 years ago, the Intertropical Convergence Zone (ITCZ) was deviated more from the Equator, carrying rain closer to the Tropic of Cancer during northern hemisphere's summer. Therefore more precipitation was delivered to southern Sahara as well as to Arabian Peninsula [11] [12]. This was the trigger factor responsible for establishing the African Humid Period (AHP) and development of Green Sahara phenomenon.

Unlike during the Last Ice Age, when Sahara was a hyperarid and inhospitable desert and human settlements were limited to the Nile river valley, during the Greenlandian Stage people avoided frequently and severely flooded banks of this river and moved to more elevated areas that meanwhile became savanna thanks to abundant rainfall [13]. During the Greenlandian Paleolithic and Mesolithic 
nomadic civilizations existed all over Sahara but in the Nile valley.

Most people in the Greenlandian Stage were still hunters-gatherers but at multiple isolated places on Earth the first domestication of plants and animals took place. Several animal species were domesticated, among them pigs (in multiple locations in Asia), cows (in the Middle East and Sahara [14]), donkeys, goats and camels in the Middle East, buffalos and zebu cattle in India and horses in eastern European steppe. Unlike domestication of animals which allowed to continue a nomadic style of living, domestication of plants required sedentary life. Domestication of plants occurred independently at several locations. Among many domesticated plants wheat, barley, oats, rye, peas, flax and figs in the Middle East, sorghum in western Africa, cotton, sesame and dates in India, millet and soybean in northern China, rice and hemp in southern China and maize, tomatoes, cocoa and potatoes in America were domesticated that time. By the end of the Greenlandian Stage domesticated plants and animals at several places on the Earth became so much better than the wild varieties that they became treated as a treasure deserving protection of their owners. Humans became attached to their cattle and fields, they got to know the sense of land ownership.

\section{The Northgrippian Stage ( 8300 - 4200 years ago)}

After about 500 years of cooling, called the $8.2 \mathrm{ky}$ event, a new warm period, the Northgrippian Stage, began. At its beginning the Northgrippian was the warmest and the wettest period of the Holocene because the axial tilt was close to its maximum but throughout this stage solar insolation of the northern hemisphere was slowly decreasing because the axial tilt of the Earth was diminishing. Despite that, due to simultaneous melting of remnants of ice sheets and progressive afforestation of high latitudes, a mean global temperature reached its Holocene maximum. About 7500 years ago an average temperature on Earth became even by $2^{\circ} \mathrm{C}$ higher than at the beginning of the current millennium, and in Scandinavia and Siberia it might have been even $6^{\circ} \mathrm{C}$ higher [15].

Although at the beginning of the Northgrippian Sahara was still a savanna, it was during the Northgrippian Stage when Sahara was getting progressively drier and finally became a desert. Since about 8.7 ky ago the Nile runoff was progressively diminishing and floods in the Nile valley became less devastating. This allowed people to reoccupy this valley about 7500 years ago. With further desiccation of Sahara, people started abandoning Sahara about 5500 years ago [16] [17] [18]. Abandoning of Sahara was coincident with the development of a new era, the Neolith.

During the Northgrippian widespread domestication of plants and animals provided abundance of food and caused a demographic explosion. An extremely humid climate of the early Northgrippian Stage allowed people to prosper without risk of drought and hunger. Higher density of population led to development of specialties. Sedentary style of life encouraged to take care of tools and houses. The evolution in human skills did not happen within a life of one generation but to distinguish it from almost imperceptible progress 
throughout 200,000 years of the Paleolithic Age this rapid development of human skills is called pathetically "the Neolithic Revolution". During the Northgrippian Stage the first human civilizations developed. All of them appeared in the northern hemisphere just north from the tropic of Cancer, in areas that were still within the reach of northern Middle-Latitudes Westerlies but warm and therefore prone to desiccation.

The first cities were established independently at multiple continents. Most of them appeared on foothills, far from big rivers. An area where such cities were particularly numerous is called the Fertile Crescent and it stretched from what is today Israel through northern Syria and northern Iraq to western Iran (Zagros Mountains). This area is also called "the cradle of civilization" because most of contemporarily used varieties of animals and plants were domesticated there. This civilization was based on the cultivation of cereals showing long-day photoperiodic response (barley, wheat, oats and rye) [19], which means that they blossom before the day begins to shorten (before the end of June). Some of them are winter cereals, planted in autumn and harvested in late spring or early summer. These cereals do not require summer rain and their cultivation relies mainly on the moisture stored in winter. This type of agriculture is called today the "dryland farming". Distribution of the first large cities on highlands, far from big rivers proves that during the Neolithic Revolution the annual precipitation in this region was higher than today while the type of domesticated plants suggests that most precipitation occurred during winter when the prevailing humid winds blew from the west and high yields initially could be achieved only in the beginning of summer [20] [21].

Because of continued desiccation of eastern Sahara people changed their style of life from hunters-gatherers to nomadic herders practicing the cult of the cattle [22]. They appeared in the Nile valley about 7.5 ky ago [13]. At first people settled along the Nile and in oases [23] [24] [25] [26] but in the Nile delta that was still marshy and prone to devastating floods and therefore was inhabited later. They brought to Egypt the cult of cattle and a custom to build tombs. The Old Kingdom in Egypt was established about 4700 years ago (about 2700 BC). It was in this oldest Neolithic period that the most impressive buildings of Egypt, including Sphinx and pyramids, were built.

The biggest Neolithic civilization, Sumer, developed in the eastern part of the Fertile Crescent. Primarily it consisted of many independent city-states with a relatively egalitarian system. Sumerian cities sometimes fought and sometimes cooperated with each other which stimulated trade, military and bureaucracy. The development of trade also supported development of metalworking, because tin and copper mines occur in different places and these two metals must be smelted separately (at different temperatures) before making bronze alloy. Thanks to the development of trade by the end of Sumer civilization the Bronze Age in Mesopotamia began [27]. Sumerian city-states were united about 4400 years ago by Sargon the Great, the Akkadian King. This provided a long-lasting 
peace and allowed a multilingual society to flourish.

The most impressive example of the Neolithic Indus Valley Civilization are the ruins of Mehrgarh in Baluchistan dated 9000 - 4500 years ago, located several hundred kilometers north from the Indus river at the foothills near the border with Afghanistan [28]. These areas are nowadays semi-arid or desert. This location suggests that at the time the rainfall there was regular and sufficient to support the development of big cities. The name "Indus valley civilization" can be misleading because in its urban stage, before the $4.2 \mathrm{ky}$ event, its large Neolithic cities were located far from Indus, either in Baluchistan or around the Thar desert (for example Mohenjo-Daro, Harappa, Dholavira).

Remnants of the earliest civilizations in China are also located mainly in northern highlands: on the Loess Plateau and in today's Inner Mongolia. The Yangshao, Qijia, Laohushan and Longshan cultures thrived in areas that today suffer from water shortages. This proves that regular and abundant precipitation carried by the East Asian Monsoon reached almost one thousand kilometers further north than today [29]-[34], although orbital forcing can explain only about $120 \mathrm{~km}$ shift northward, comparing to today's values. This could have been caused by larger precipitation carried by Middle-Latitudes Westerlies (MLW), especially during the colder semester. Thanks to slightly higher winter precipitation resulting in an increased plant cover and a lower albedo during spring and early summer, convection of air above these areas increased low-level humid winds carried by summer monsoon. Types of cereals cultivated in northern China and Inner Mongolia (millet) as well as in the Yangtze River valley (rice) also suggest regular and abundant summer monsoon rain which favored cultivation of these cereals. They are "short-day plants", which means that they grow best after days begin to shorten.

The processes of society forming and state development occurred independently in Egypt, the Fertile Crescent, Indus valley and northern China. However, before the $4.2 \mathrm{ky}$ event Neolithic city-states were relatively loosely organized and their agriculture relied rather on water stored in soil during winter rainy season or on summer rainfall than on irrigation canals that were not frequently built yet and primitive [35] [36] [37] [38]. Due to establishment of international trade, Neolithic civilizations of Egypt, the Middle East and India communicated with each other, as evidenced by a spread of wheat and barley all over these places as well as similar pottery and tools. Wheat and barley seeds were found also in the city of Sarazm (today's western Tajikistan, on foothills of Pamir mountains) that is considered a Neolithic center of metallurgy [39]. That time China was isolated from other civilizations, as can be deduced from the type of cereals: millet and rice were not found outside eastern Asia, also barley was not present in China that time.

Another achievement of civilization was the invention of writing which, like the domestication of cereals and animals, also proceeded independently in Egypt, the Middle East, India and China. Reading these records provides information about 
life and events in the Neolith [40] [41].

\section{The 4.2 ky event (The Great Drought)}

About 4200 years ago the climate became colder and drier for about 200 years, especially all along the Tropic of Cancer [42] [43]. Unlike the Younger Dryas or the 8.2 ky event, its origin cannot be explained by an outflow of meltwater from proglacial lakes because it was not followed by an elevation of sea level. Moreover, it was not accompanied by cold and dry conditions in Europe [44] which means that the thermohaline deep water circulation in the northern Atlantic was not disrupted. Drought and cooling resulted in simultaneous termination of the Old Kingdom in Egypt, the Akkadian Empire, the urban Indus Valley Civilization (the Harappan Civilization), Neolithic civilizations in China and a number of smaller Neolithic civilizations.

\section{The origin of the $4.2 \mathrm{ky}$ event}

Until now, no satisfactory explanation of the origin of the $4.2 \mathrm{ky}$ event is proposed. Some hypotheses were formulated but they are not widely accepted. For example, a weaker solar irradiation and changes in oceanic circulation showing a 1500-year periodicity (Bond events) were analyzed [45] [46]. Although this hypothesis has never been fully rejected [47] it is currently generally accepted that smaller solar activity was not potent enough factor to trigger this event [48] [49]. No convincing data confirming a volcanic eruption [50] or planetoid impact are available from that time. Therefore, the role of anthropogenic desertification is increasingly analyzed [7] [8] [9] [10]. Probably several factors contributed to the development of the $4.2 \mathrm{ky}$ event, some of them may be unknown today. One of the arguments for anthropogenic character of the Great Drought and against its solar and/or volcanic origin is that it apparently occurred about $1-2$ centuries later in China [51] [52] than in the Middle East or northern India. The collapse of Chinese civilizations can be explained by progressive strengthening of the Asian High Pressure System (Siberian High) that develops in Asia during winter. This resulted in smaller precipitation carried by the Middle-Latitudes Westerlies (MLW). During winter, both stronger Siberian High that brings dry and cold wind to China as well as weaker MLW caused aridification of Inner Mongolia which increased albedo, cooled the climate there and subsequently resulted in a decreased extent of the East Asian Monsoon during summer.

Except for symptoms of cold and dry weather during the $4.2 \mathrm{ky}$ event, two features were discovered that can be helpful to explain the origin of this disaster. The first is a short episode of an elevated Sea Surface Temperature (SST) in the western Indian Ocean that happened 4.2 ky ago despite global cooling [53] [54] accompanied by a decreased upwelling off the shore of Somalia [55] which suggests weakening of the Indian Summer Monsoon-driving wind. The second are data obtained from a cave in Kyrgyzstan (Pamir mountains) which indicate that a long-lasting dry period from 4700 to 3900 years ago was interrupted by a short episode of increased precipitation around 4200 years ago [56].

It is difficult to explain weakening of the Indian Summer Monsoon when it 
coincides with a higher SST of the western Indian Ocean. Usually, the Indian Summer Monsoon is stronger (brings heavier summer rainfall) when the SST of the western Indian Ocean is higher because higher SST means that the Indian Ocean Warm Pool (IOWP), the source of warm moisture for monsoons, is bigger. The surprising increase of SST in the western Indian Ocean accompanied by weaker Indian Summer Monsoon-driving wind and dry conditions in India 4.2 ky ago cannot be explained by a change in solar radiative activity nor changes in thermohaline circulation in the Atlantic Ocean. Moreover, data from temperate climate areas do not confirm that [44] [57]. It is possible that the phenomenon that inhibited the ISM that time is still waiting to be discovered. However, data assessing precipitation evolution obtained from Pamir mountains showing a long-lasting dry period from 4700 to 3900 years ago that was interrupted by a short episode of increased precipitation around 4200 years ago allow putting a following hypothesis.

It can be hypothesized that a multicentennial drought lasting for 800 years, from 4700 to 3900 years ago, was caused by a massive deforestation, overgrazing and appliance of deliberate wildfires in areas prone to desiccation. Practices called "fire-stick farming" are applied by Australian Aborigines even recently [58] [59]. Applied throughout the Northgrippian Stage the use of wildfires probably added to desiccation of savanna in Sahara and accelerated its desertification [9]. Also in the Middle East the use of deliberate wildfires in savanna and steppe could have been responsible for an increased evaporation of water from soil deprived of plant canopy which resulted in a progressive lowering of the groundwater level. Another factor accelerating desiccation was the development of goat and camel husbandry. These animals are rather browsers than grazers which means that they feed on shrubs and trees rather than on grass. Overgrazing added to destruction of bushes and trees by people and contributed to the desertification of steppe and savanna. It can be hypothesized that a long-lasting period of progressive drying as evidenced in a cave in Pamir reflects a multi-centennial large-scale persistent appliance of similar practices by a rapidly growing human population.

The evidence of increased precipitation in the Pamir around 4200 years ago, during the Great Drought in the Middle East, is surprising. Pamir is beyond the reach of humid Indian Summer Monsoon and receives its precipitation entirely from the Middle-Latitudes Westerlies (MLW). Since there was a drought west of Pamir (in the Middle East), the only source of increased precipitation in the Pamir at the time had to be increased evaporation in the Middle East. Therefore, to find a relationship between the episode of sudden rise in Pamir mountains' precipitation about 4.2 years ago and the development of the 4.2 ky event, reference should be made to the chronicles written by the Sumerian scribes.

Tablets written with cuneiform script contain information about a gradual decline of the Akkadian Empire which manifested, among others, in the loss of its peripheral provinces. However, its final collapse is related to the war between the 
Akkadian Empire and the Gutians, people who came from Zagros mountains who earlier conquered Elam (south-east of Akkad). In the "Lamentation over the Destruction of Ur" (title given by its translator, Samuel Kramer) we read: "Enlil (powerful Sumerian deity) brings Gibil (the God of fire) to his aid" or "in front of the storms fire burnt" and "To the battling storms was joined the scorching heat. [...] Fire burnt" while in the "Lamentation Over the Destruction of Sumer and Ur" we learn about a series of unlucky alliances of Shu-turul, the last king of Akkad, which finally led to invasion of nomadic tribes, the Gutians. Gutians "laid waste to the [steppe] (and) whatever flourished in it, none could travel there" [60].

Sumerians called themselves "black-headed" to distinguish themselves from the invaders, therefore it can be hypothesized that the Gutians were blond hair Indo-Europeans [61]. If so, they were probably horsemen as well, because horses were domesticated in the Pontic steppe, where Indo-Europeans originated. The first images of horses appeared in Sumer shortly before the 4.2 ky event [62], but the first Sumerian picture of a horse-rider is dated at $2050 \mathrm{BC}$, the last year of Gutian occupation [63]. It is highly likely that putting on fire was a method of destruction which was probably the dominant tactics applied during this war, especially by the Gutians. Cuneiform script tablets do not describe great battles during this invasion, they depict only destruction. Vast areas of the Akkadian Empire and adjacent land were destroyed, possibly by fire. Land deprived of protective plants was losing moisture rapidly. During several years of this war the groundwater level dropped, as evidenced by disappearance of some rivers ("in the rivers of my city dust has gathered [...] in their midst no sparkling waters flow") [60]. As the wildfires are easiest to set at the end of dry summer, in autumn soil covered with charcoal was easier warming up, excessively evaporating water that was subsequently carried to the east by the Middle-Latitudes Westerlies (MLW). According to the chronicles, the Gutians' invasion and occupation lasted 34 years and finished in year 2050 BC when they were defeated by Sumerians and a new Sumerian dynasty was established.

It can be hypothesized that water that evaporated from the Middle East during that war was carried by Middle-Latitudes Westerlies eastward, and subsequently caused an increased snowfall in mountains surrounding the western Tibet around $4.2 \mathrm{ky}$ ago, recorded as an episode of increased precipitation in the middle of a long-lasting dry period, as evidenced from a drip-stone in Pamir mountains [56] [Figure 2]. This increased precipitation resulted in a rapid growth of snow cover and glaciers in mountains surrounding the western Tibet (Pamir, Hindukush and the Himalayas) which lasted for several decades. This snow cover did not last long enough to create significant glacier moraines but lasted long enough to decrease the albedo of these mountains and cause a potent cell of high air pressure over them. This high-pressure cell enlarged the extent of the Siberian High during winter, increased the strength of the winter monsoon in India and contributed to the development of dry and cold conditions in the Deccan Peninsula, lasting for almost two centuries [Figure 3]. The cell of a high air 


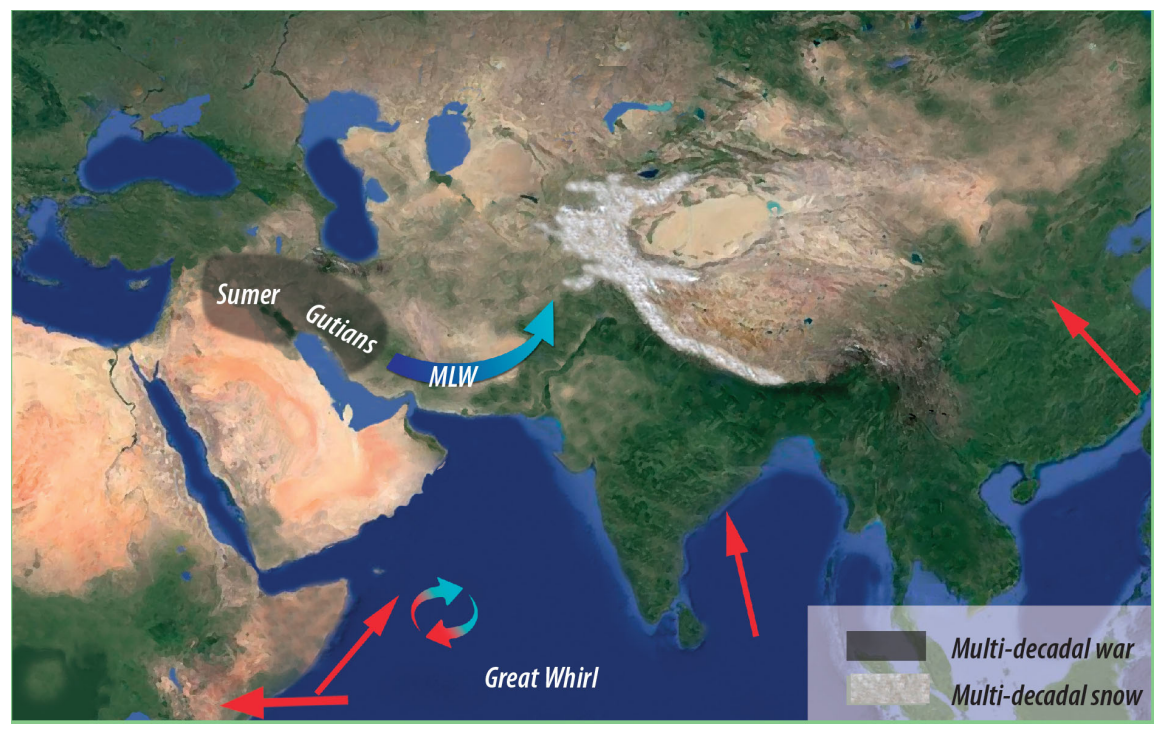

Figure 2. The origin of the $4.2 \mathrm{ky}$ event. Multidecadal war and wildfires in the Middle East caused a multidecadal snow cover in mountains around western part of Tibet. Curved arrow shows the direction of transport of moisture by MLW. Straight arrows show the strength and prevalent direction of monsoon-driving winds.

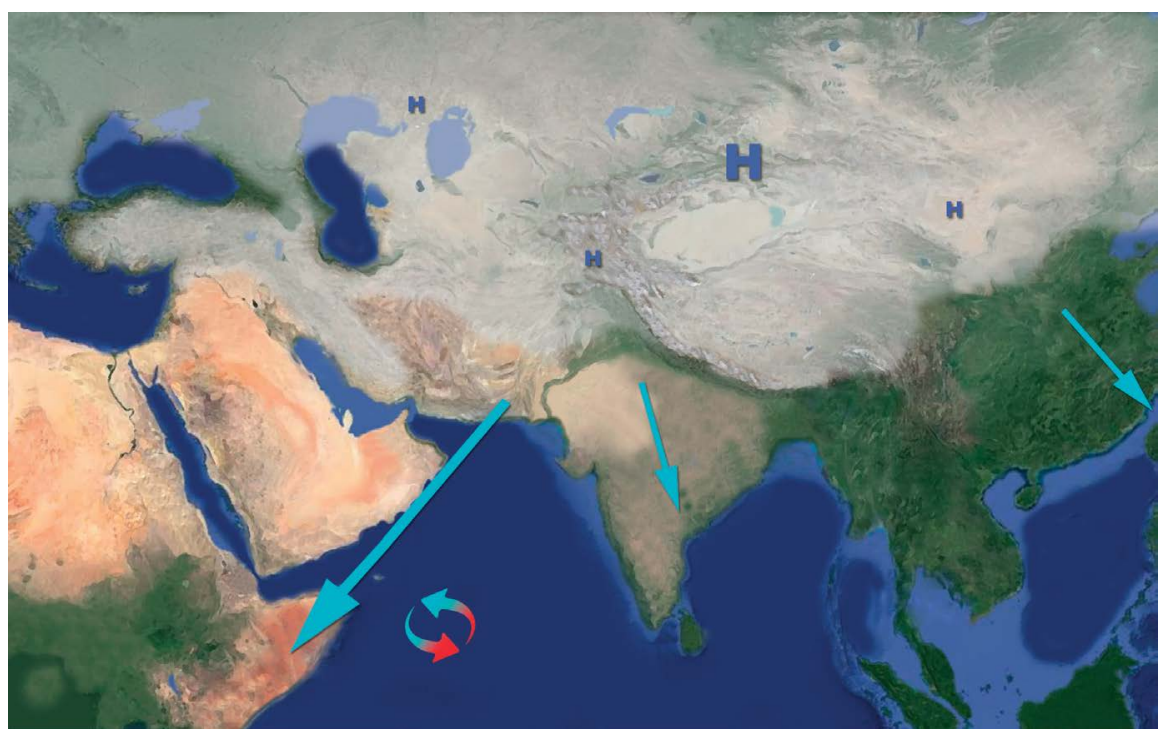

Figure 3. The Great Drought during winter. An extremely strong Indian Winter Monsoon caused cold and dry conditions in the Horn of Africa, as well as drought in Deccan Peninsula. It also reversed the Great Whirl east off the coast of Somalia. Straight arrows show the strength and prevalent direction of monsoon-driving winds. H-high pressure area.

pressure over Pamir and the Himalayas became an obstacle for the MLW that provide annual precipitation to western part of Tibetan Plateau, therefore the lake level there was extremely low at the time [64]. It can be further hypothesized that this snow cover, due to a potent cell of high air pressure over it, suppressed the Indian Summer Monsoon-driving wind which resulted in a smaller summer precipitation in the Indian subcontinent. Due to weaker wind driving 
the Indian Summer Monsoon (as evidenced by a decreased upwelling off the Somalian shore [55]), the Sea Surface Temperature (SST) in the western Indian Ocean increased that time [53] [54] [Figure 4].

The description of Gutian invasion was probably the first such extensive description of Indo-Europeans, whose main contribution to the development of civilization in the Neolith was domestication of horses. As Gutians, unlike Akkadians, were probably not commonly equipped with bronze swards and armor, horses and fire were their main weapon. The Gutian invasion of the Middle East started probably several decades before they conquered Akkad, with invasion on the Iranian Plateau and Elam. This corresponds well with the onset of the $4.2 \mathrm{ky}$ event. After Gutian invasions, during the next centuries horses had spread out all over Eurasia which influenced methods of transportation and waging wars [65].

The Great Drought in China occurred at least 100 years later and probably had bigger impact on the development of civilization than anywhere else. Bamboo Annals and scientific research show that the first system of irrigation canals that aimed to distribute the summer floods' water was built around 4100 years ago, after inhabitants have moved from drying highlands into alluvial plains in the Yellow River delta [51]. Construction of this canal system is accredited to the founder of the first Chinese dynasty. Building canals enabled humans to exploit agriculturally Huang-he plains that previously had been unhospitable marshes. This was coincident with a drought that forced people to leave their highland headquarters. Both northern highland civilizations based on the cultivation of millet and southern civilizations based on cultivation of rice collapsed at about the same time, that is about 4000 years ago. It is believed that the cause of the fall of northern Chinese civilizations were alternating droughts and floods [66] as

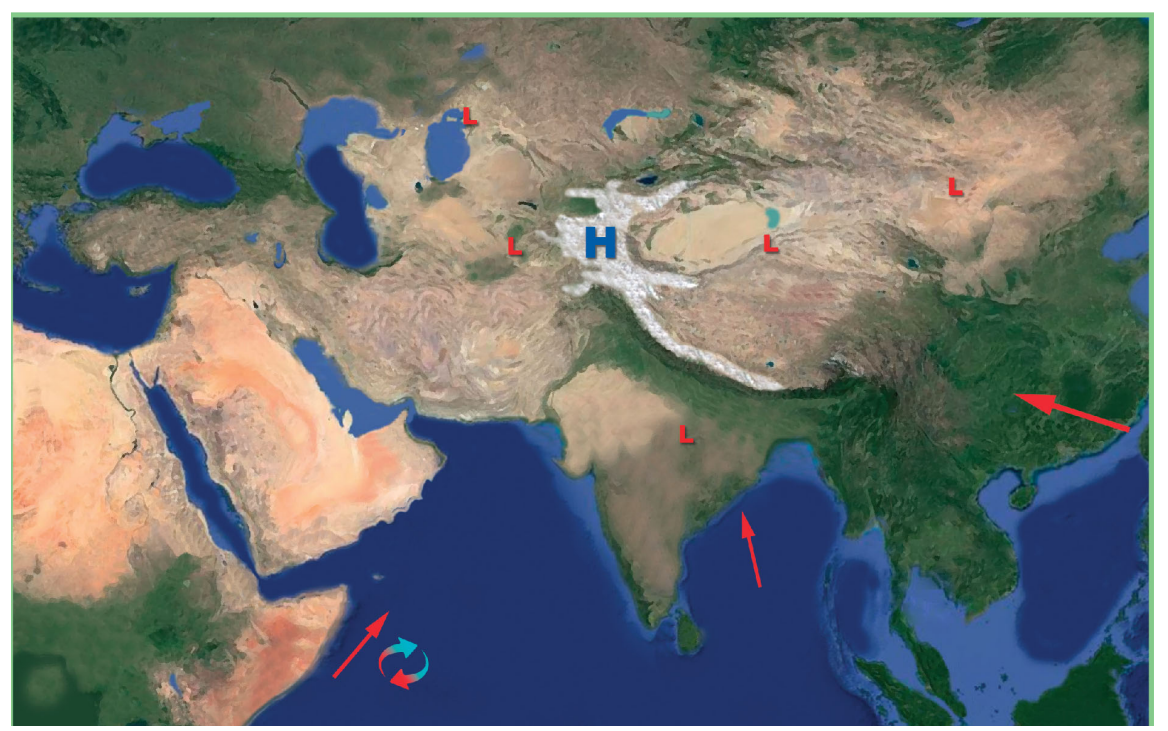

Figure 4. The Great Drought during summer. Note weaker low air pressure area which causes weaker Indian Summer Monsoon. Straight arrows show the strength and prevalent direction of monsoon-driving winds. L: low pressure area. 
well as cooling of the climate while the cause of the collapse of southern civilizations were unpredictable and violent floods [67]. This reflects the decrease in the coverage area of the East Asian Monsoon in northern China and shifting its main vector to the south, to the basin of the Yangtze River which could have been caused by stronger Siberian High.

Assuming that the boreal East African Monsoon (bEAM) and the Indian Summer Monsoon (ISM) compete with each other for heat and moisture stored during spring in the Indian Ocean Warm Pool, the increased SST of the western Indian Ocean during the 4.2 ky event combined with weaker ISM should be accompanied with stronger summer boreal East African Monsoon (bEAM) and stronger spring and autumn precipitation related to Walker circulation. Nonetheless, eastern Africa experienced an extreme drought that time, as evidenced by low level of equatorial lakes [68], decrease in the Kilimanjaro glacier extent and extremely large amount of dust deposit in this glacier [69]. This can be explained by the hypothesis that the extremely strong Indian Winter Monsoon combined with the extremely weak Indian Summer Monsoon caused reverse rotation of the Great Whirl located east from the Horn of Africa that normally rotates clockwise. This potent gyre acts as a flywheel that supports the development of boreal summer monsoons originating in the western Indian Ocean. Hypothetical anti-clockwise rotation of this gyre during the $4.2 \mathrm{ky}$ event could have caused further weakening of the ISM as well as bEAM and especially weakening of the Walker circulation, therefore spring and autumn precipitation in equatorial East Africa was sparse that time. Additionally, winds driven by an extremely potent Siberian High could have reached as far south as to modern-day Kenya, bringing dust from the Arabian Peninsula and the Horn of Africa [Figure 3, Figure 5]. Despite extremely dry conditions in eastern Africa that time
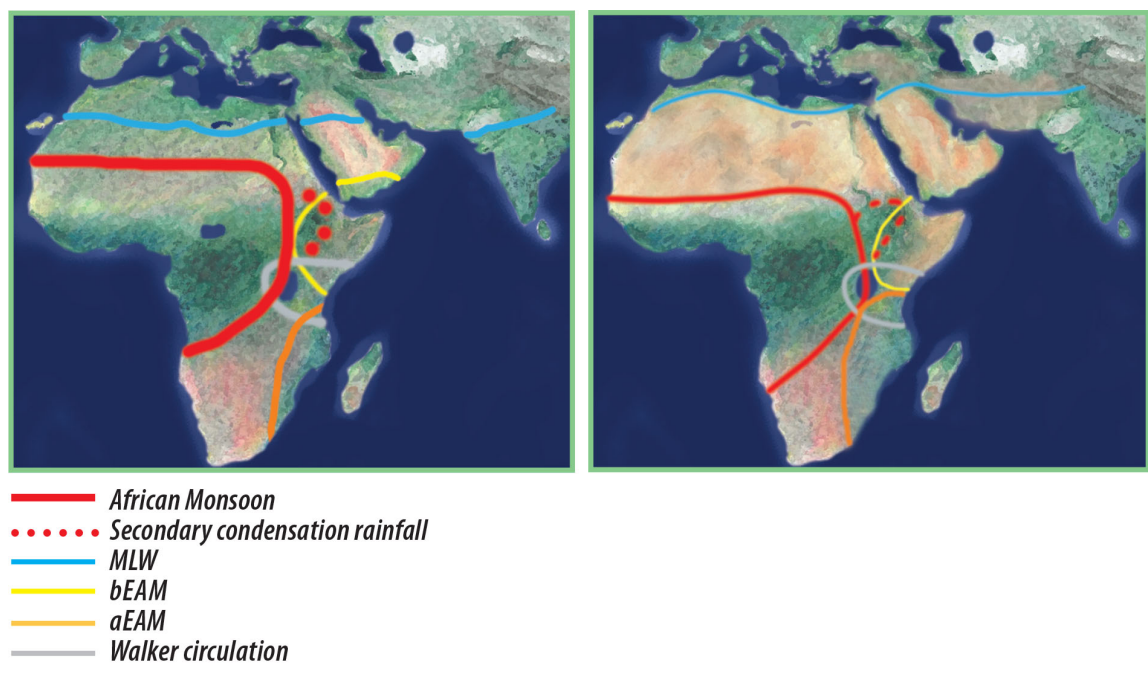

Figure 5. Monsoons and plant canopy in Africa before aridification of Sahara and during 4.2 ky event. Within only 700 years Sahara became a desert. Also monsoons in the northern hemisphere's Africa became permanently weaker. This time span coincided with the Neolith in Africa and the Middle East. 
(dust in Kilimanjaro), the Nile outflow during the $4.2 \mathrm{ky}$ event remained relatively stable because since about $5.3 \mathrm{ky}$ ago a significant part of precipitation in the Blue Nile sources (Ethiopian Highlands) originated from Congo river basin, not from the boreal East African Monsoon [70], as a secondary condensation rainfall. Due to weaker Walker circulation at the time, precipitation around equatorial Great Lakes in Africa diminished, therefore the White Nile (originating in Lake Victoria, with its peak outflow in spring and autumn) became smaller than the Blue Nile (originating in Ethiopian Highlands, with a peak outflow in summer). This resulted in shortening of the flooding period in Egypt, contributed to the collapse of the Old Kingdom and forced Egyptians to build canals to irrigate fields between floods [Figure 5].

Drought in the Middle East and in India resulted in a higher albedo of these areas. Also increased permanent snow cover in mountains adjacent to Tibet was responsible for increased albedo. Assuming that albedo increased by $20 \%$ in the area of about 5 million $\mathrm{km}^{2}$, it greatly influenced the amount of absorbed solar radiation in these areas. Although they comprise only about $1 \%$ of the total Earth's surface, they are located relatively close to the Equator, therefore they comprise about $2 \%$ of the Earth's shadow area. If we add to this a prolonged snow cover at high latitudes and dry conditions in eastern Africa, then we can assume that the albedo of the entire planet has increased, for example, from 0.3 to 0.32 . The absorbed solar radiation can be calculated according to the formula:

Equation 1 [15]:

$$
\text { Absorbed solar radiation }=S_{0}(1-\alpha) \pi r^{2}
$$

where $S_{0}$ is a solar constant $\left(1367 \mathrm{Wm}^{-2}\right), \alpha$ is albedo and $r$ is the Earth's radius $(6,371,000 \mathrm{~m})$. This decrease in absorbed solar radiation resulted in lower emission temperature of the Earth. Emission temperature of the Earth is calculated according to the formula:

Equation 2 [15]:

$$
T_{e}=\sqrt[4]{\frac{\left(\frac{S_{0}}{4}\right)(1-\alpha)}{\sigma}}
$$

where $T_{e}$ is the emission temperature of the planet and $\sigma$ is the Stefan-Boltzmann constant $\left(5.67 \times 10^{-8} \mathrm{~W} \cdot \mathrm{m}^{-2} \cdot \mathrm{K}^{-4}\right)$.

As can be calculated from the above formula, for albedo 0.3 the emission temperature of the Earth $\left(T_{e}\right)$ is about $255 \mathrm{~K}\left(-18^{\circ} \mathrm{C}\right)$ while for albedo $0.32 T_{e}$ is about $253 \mathrm{~K}\left(-20^{\circ} \mathrm{C}\right)$. If during the $4.2 \mathrm{ky}$ event the emission temperature dropped by about $2^{\circ} \mathrm{C}$, also the actual temperature (which is about $33^{\circ} \mathrm{C}$ higher than the emission temperature because of the greenhouse effect) dropped by about $2^{\circ} \mathrm{C}$. This explains cold and dry conditions all over the globe.

It must be emphasized that according to resent computerized climate simulations the mean global temperature dropped by much less than that, by about $0.2^{\circ} \mathrm{C}$ [71]. However, these simulations did not take into account the changed 
albedo of the planet. By comparison to current global warming (by about $1^{\circ} \mathrm{C}$ in about 100 years) which has not caused similar disaster, it seems unlikely that the collapse of all Neolithic civilizations was a result of such minor drop in temperature. Analyzing several factors (orbital forcing, glacial ice cover, carbon dioxide concentration in the atmosphere, meltwater flux and combination of all of aforementioned factors together) these authors came to the conclusion that the global drought and cooling was present only in the northern hemisphere, especially all along the Tropic of Cancer and that it was caused by "internal variability" [71] [72] which means that it was caused by accidental coexistence of several meteorological phenomena (like combination of stronger Azorean High and Icelandic Low air pressure systems). However, the latter could be a result not a cause of the $4.2 \mathrm{ky}$ event because this combination did not lead to stronger MLW, as it usually does. Therefore another explanation of the origin of the 4.2 ky event could be proposed: a development of a multidecadal high pressure area over the core of Asia which inhibited MLW and subsequently hold back both Azorean High and Icelandic Low over the Northern Atlantic. Staying of Azorean High and Icelandic Low over the Northern Atlantic made them stronger than usual. Prolonged stronger Azorean High coincides with drought around the Mediterranean Sea and in the Middle East [73] which probably happened also 4.2 thousand years ago.

The global cooling caused a series of disasters. Data from the studies assessing the Nile outflow confirm a decreased discharge of the Nile that time, especially lower White Nile runoff which reflects weaker Walker circulation [74]. The cold and dry climate in Egypt was probably also influenced by decreased winter rainfall (weaker MLW) resulting from strong Siberian High and/or a global cooling of the climate caused by increased albedo of the entire planet. During the $4.2 \mathrm{ky}$ event, the global temperature dropped and climate became dry all over the globe, including both Americas, as documented for example from glaciers in the Andes [75] and a low level of lakes in the North America [76].

Even bigger mystery than the cause of the $4.2 \mathrm{ky}$ event is the reason why it had terminated. Especially because prolonged cold conditions in the core of Asia caused permafrost to grow, as documented by a prolonged decrease in air temperature from about 4000 to 2600 years ago in the Altai mountains [77]. Whatever was the cause, the retreat of the Siberian High, at least partially, returned winter precipitation in the Middle East but not in the northern India and northern China. By the end of the Great Drought, summer heating melted the multidecadal snow cover in mountains around Tibet and a high air pressure cell over them disappeared. This allowed the ISM to return which provided abundant rainfall to the central and southern India. The revived plant canopy in Deccan decreased albedo there and raised the local and global temperature almost to values observed before the $4.2 \mathrm{ky}$ event.

The Meghalayan Stage (4.2 kiloyears ago until present)

The history of the Mankind during the Meghalayan Stage is a history of a 
struggle against slowly but progressively deteriorating conditions for agriculture and living. The $4.2 \mathrm{ky}$ event became a challenge and a stimulus to societies which they fought successfully thanks to a better organization of states and technological progress. In Egypt, the establishment of the Middle Kingdom by Theban pharaohs was simultaneous with a mass construction of irrigation canals in the Nile valley and in the Nile delta [78] [79]. In Mesopotamia, after people abandoned Neolithic cities in highlands, new cities were built either on plains or on banks of big rivers. Irrigation canals allowed to exploit snowmelt water flowing from Zagros Mountains and harvesting twice a year became possible [80] which supported a further growth of the civilization. Development of states also gave impulse to the establishing of a legal system [81] [82], to defend order and peace.

In northern India, where an early Harappan civilization flourished before the 4.2 ky event, people abandoned Neolithic big cities located in foothills north from Indus river and the late Harappan civilization settlements were built either on the banks of Indus river or in Punjab, where the Indian Summer Monsoon delivered sufficient precipitation [83] [84] [85]. However, the late Indus civilization was characterized by a number of small towns and villages instead of big cities [86] [87] [88] which proves a decline in organization. This made the Indus valley civilization susceptible to Indo-European infiltration and subsequent domination.

The first canals built in the Huang-he delta aimed rather to distribute the excess of water during severe floods than to irrigate fields during dry periods. However, during the Meghalayan Stage, the extent of summer monsoon in northern part of China has been progressively decreasing, therefore today these canals aim to provide drying fields with water. The shortage of water forces the contemporary Chinese government to draw expensive plans for redirecting rivers from the Yangtze basin into the Huang-he basin [89].

In the beginning of the Meghalayan Stage, thanks to the development of states harvesting twice a year became a regular practice. Large states, through their military and legal systems, ensured peace and safe trade that helped to widespread production of bronze tools. The Bronze Age developed all over the Old World. Almost concomitantly people learned to produce iron tools, and this skill had spread from Europe and the Middle East to Egypt, India and China within the next millennium. The lesson how people coped with deteriorating conditions after the Great Drought allows to conclude that periods of less favorable conditions for living have been the strongest impulse for the development of civilization.

\section{Discussion}

It is now commonly accepted that the current global warming is caused by humans, namely by anthropogenic emission of greenhouse gases, especially carbon dioxide. It is justifiably considered to be one of the biggest threats for life on the planet and human civilization. However, humans probably have been changing 
the climate locally and even globally since millennia. The development of agriculture and animal husbandry has been increasing the albedo of the planet progressively. The cooling of the climate since the Neolithic Revolution which lasted until the onset of the Industrial Revolution corresponds better with the growth of human population than with any other factor. It is possible that the current global warming only balances the global cooling caused by our predecessors. However, there is a huge difference between the current Earth and the Earth during the Holocene Climatic Optimum. Today our planet is greatly deprived of plant canopy, fertile soils and peat bogs which were so common during most of the Holocene. The current progressive deforestation in Brazil and Indonesia further adds to this process. The hypothesis presented in this paper suggesting that the $4.2 \mathrm{ky}$ event was caused by humans deserves attention not only because the origin of this event is still not explained. If it is confirmed in further field investigations (for example in an analysis of drip stones from caves in mountains surrounding western part of Tibet) and computerized simulations, it can be a lesson how people can change the course of monsoons and MLW. This knowledge could teach us how to direct water to desiccating areas. This might even help us to use the current global warming as a tool to restore conditions resembling the Holocene Climatic Optimum. If this would be achieved, the global warming would be curbed. It seems that the most efficient and the safest method to limit the negative consequences of the current global warming will be inviting the plant canopy to fight the elevated concentration of carbon dioxide in the atmosphere. Flush vegetation would not only assimilate the carbon dioxide from the atmosphere but it would also decrease albedo of the planet and fix the global temperature on higher level than the temperature observed before the onset of the Industrial Revolution.

\section{Conclusion}

Humans have been changing the global climate since the Neolith. Because of their impact on the Earth's climate, the mean global temperature was decreasing. This was because the development of agriculture and animal husbandry has been increasing albedo of the planet. The cooling was proceeding despite growing $\mathrm{CO}_{2}$ concentration in the atmosphere caused by a loss of carbon from soils, forests and peat bogs. It corresponded better with the size of human population and their use of land for agriculture than with decreasing axial tilt of the Earth's orbit. It proves that before the Industrial Era, the cooling effect of increasing albedo of the planet was stronger than the warming effect of growing $\mathrm{CO}_{2}$ atmospheric concentration. Since combustion of fossil fuels became a new engine for development of civilization, the global temperature started growing. A hypothesis is formulated that the severe drought and cooling which resulted in termination of all Neolithic civilizations ( 4.2 ky event) were caused by human activity, namely by a rapid desiccation of the Middle East caused by Gutian invasions. It is hypothesized that water which evaporated from invaded countries 
was transported by Middle-Latitudes Westerlies and caused a multidecadal enlargement of glaciers in mountains surrounding western Tibet. A potent cell of high air pressure over these glaciers suppressed the Indian Summer Monsoon and increased the Siberian High. Subsequently, all prevalent humid winds on the Earth were affected for almost two centuries. This hypothesis was formulated because until now no satisfactory explanation of the origin of the $4.2 \mathrm{ky}$ event is proposed. If this hypothesis is confirmed, it can serve as a lesson how people can influence monsoons and other potent terrestrial humid winds. This knowledge can be used in the future to direct water to central Asia and Sahara, to fight the negative consequences of global warming.

\section{Conflicts of Interest}

The author declares no conflicts of interest regarding the publication of this paper.

\section{References}

[1] Indermühle, A., Stocker, T.F., Joos, F., Fischer, H., Smith, H.J., Wahlen, M., Meyer, R., et al. (1999) Holocene Carbon-Cycle Dynamics Based on $\mathrm{CO}_{2}$ Trapped in Ice at Taylor Dome, Antarctica. Nature, 398, 121. https://doi.org/10.1038/18158

[2] Walker, M., Head, M.H., Berklehammer, M., Bjorck, S., Cheng, H., Cwynar, L., Newnham, R., et al. (2018) Formal Ratification of the Subdivision of the Holocene Series/Epoch (Quaternary System/Period): Two New Global Boundary Stratotype Sections and Points (GSSPs) and Three New Stages/Subseries. https://doi.org/10.18814/epiiugs/2018/018016

[3] Ellison, C.R., Chapman, M.R. and Hall, I.R. (2006) Surface and Deep Ocean Interactions during the Cold Climate Event 8200 Years Ago. Science, 312, 1929-1932. https://doi.org/10.1126/science.1127213

[4] Von Grafenstein, U., Erlenkeuser, H., Müller, J., Jouzel, J. and Johnsen, S. (1998) The Cold Event 8200 Years Ago Documented in Oxygen Isotope Records of Precipitation in Europe and Greenland. Climate Dynamics, 14, 73-81. https://doi.org/10.1007/s003820050210

[5] Nebout, N.C., Turon, J.L., Zahn, R., Capotondi, L., Londeix, L. and Pahnke, K. (2002) Enhanced Aridity and Atmospheric High-Pressure Stability over the Western Mediterranean during the North Atlantic Cold Events of the Past 50 ky. Geology, 30, 863-866. https://doi.org/10.1130/0091-7613(2002)030<0863:EAAAHP >2.0.CO;2

[6] Blanchon, P. and Shaw, J. (1995) Reef Drowning during the Last Deglaciation: Evidence for Catastrophic Sea-Level Rise and Ice-Sheet Collapse. Geology, 23, 4-8. https://doi.org/10.1130/0091-7613(1995)023<0004:RDDTLD>2.3.CO;2

[7] Yasuda, Y., Kitagawa, H. and Nakagawa, T. (2000) The Earliest Record of Major Anthropogenic Deforestation in the Ghab Valley, Northwest Syria: A Palynological Study. Quaternary International, 73-74, 127-136. https://doi.org/10.1016/S1040-6182(00)00069-0

[8] Szczęsny, T.J. (2016) Was the 4.2 ka Event an Anthropogenic Disaster? Open Journal of Ecology, 6, Article ID: 70886. https://doi.org/10.4236/oje.2016.610058

[9] Wright, D.K. (2017) Humans as Agents in the Termination of the African Humid 
Period. Frontiers in Earth Science, 5, 4. https://doi.org/10.3389/feart.2017.00004

[10] Szczęsny, T. (2019) How to Curb the Global Warming. Part 1: The Past Climate in the Holocene. https://www.oficyna-notitia.com/online-store

[11] Parker, A., Eckersley, L., Smith, M.M., Goudie, A.S., Stokes, S., Ward, S., White, K. and Hodson, M.J. (2004) Holocene Vegetation Dynamics in the Northeastern Rub' al-Khali Desert, Arabian Peninsula: A Phytolith, Pollen and Carbon Isotope Study. Journal of Quaternary Science, 19, 665-676. https://doi.org/10.1002/jqs.880

[12] Tierney, J.E., Lewis, S.C., Cook, B.I., LeGrande, A.N. and Schmidt, G.A. (2011) Model, Proxy and Isotopic Perspectives on the East African Humid Period. Earth and Planetary Science Letters, 307, 103-112.

https://doi.org/10.1016/j.epsl.2011.04.038

[13] Kuper, R. and Kröpelin, S. (2006) Climate-Controlled Holocene Occupation in the Sahara: Motor of Africa's Evolution. Science, 313, 803-807. https://doi.org/10.1126/science.1130989

[14] Kuper, R. (2006) After 5000 BC: The Libyan Desert in Transition. Comptes Rendus Palevol, 5, 409-419. https://doi.org/10.1016/j.crpv.2005.10.013

[15] Hartman, D.L. (1994) Global Physical Climatology. Academic Press, Cambridge.

[16] Young, E. (2007) Pharaohs from the Stone Age. New Scientist, 13, 34-38. https://doi.org/10.1016/S0262-4079(07)60102-X

[17] Manning, K. and Timpson, A. (2014) The Demographic Response to Holocene Climate Change in the Sahara. Quaternary Science Reviews, 101, 28-35. https://doi.org/10.1016/j.quascirev.2014.07.003

[18] Kindermann, K., Bubenzer, O., Nussbaum, S., Riemer, H., Darius, F., Pöllath, N. and Smettan, U. (2006) Palaeoenvironment and Holocene Land Use of Djara, Western Desert of Egypt. Quaternary Science Reviews, 25, 1619-1637. https://doi.org/10.1016/j.quascirev.2005.12.005

[19] Junges, W. (1957) Die jährliche Niederschlagsverteilung Als Entscheidender Faktorbei der photoperiodischen Anpassung der Pflanzen. Gartenbauwissenschaft, 22, 527-540.

[20] Hruška, B. (1990) Das landwirtschaftliche Jahr im alten Sumer: Versuch einer zeitlichen Rekonstruktion. Bulletin on Sumerian Agriculture, 5, 105-114.

[21] Riehl, S., Bryson, R. and Pustovoytov, K. (2008) Changing Growing Conditions for Crops during the Near Eastern Bronze Age (3000-1200 BC): The Stable Carbon Isotope Evidence. Journal of Archaeological Science, 35, 1011-1022. https://doi.org/10.1016/j.jas.2007.07.003

[22] Di Lernia, S. (2006) Building Monuments, Creating Identity: Cattle Cult as a Social Response to Rapid Environmental Changes in the Holocene Sahara. Quaternary International, 151, 50-62. https://doi.org/10.1016/j.quaint.2006.01.014

[23] Krzyzaniak, L. (1991) Early Farming in the Middle Nile Basin: Recent Discoveries at Kadero (Central Sudan). Antiquity, 65, 515-532. https://doi.org/10.1017/S0003598X0008011X

[24] Lindstädter, J. and Kröpelin, S. (2004) Waki Bakht Revisited: Holocene Climate Change and Prehistoric Occupation in the Gilf Kebir Region of the Eastern Sahara, SW Egypt. Geoarcheology: An International Journal, 19, 753-778. https://doi.org/10.1002/gea.20023

[25] Moeyersons, J., Vermeersch, P.M., Beeckman, H. and van Peer, P. (1999) Holocene Environmental Changes in the Gebel Umm Hammad, Eastern Desert, Egypt. Geomorphology, 26, 297-312. https://doi.org/10.1016/S0169-555X(98)00067-1 
[26] McDonald, M.M.A. (1998) Early African Pastoralism: View from Dakhleh Oasis (South Central Egypt). Journal of Anthropological Archeology, 17, 124-142. https://doi.org/10.1006/jaar.1998.0320

[27] Crawford, H. (2013) The Sumerian World. Routledge, Abingdon-on-Thames. https://doi.org/10.4324/9780203096604

[28] Jarrige, J.F. and Meadow, R.H. (1980) The Antecedents of Civilization in the Indus Valley. Scientific American, 243, 122-137. https://doi.org/10.1038/scientificamerican0880-122

[29] An, C.B., Feng, Z.D. and Barton, L. (2006) Dry or Humid? Mid-Holocene Humidity Changes in Arid and Semi-Arid China. Quaternary Science Reviews, 25, 351-361. https://doi.org/10.1016/j.quascirev.2005.03.013

[30] Jiang, W., Guo, Z., Sun, X., Wu, H., Chu, G., Yuan, B., Guiot, J., et al. (2006) Reconstruction of Climate and Vegetation Changes of Lake Bayanchagan (Inner Mongolia): Holocene Variability of the East Asian Monsoon. Quaternary Research, 65, 411-420. https://doi.org/10.1016/j.yqres.2005.10.007

[31] Long, H., Lai, Z., Wang, N. and Li, Y. (2010) Holocene Climate Variations from Zhuyeze Terminal Lake Records in East Asian Monsoon Margin in Arid Northern China. Quaternary Research, 74, 46-56. https://doi.org/10.1016/j.yqres.2010.03.009

[32] Maher, B.A. (2008) Holocene Variability of the East Asian Summer Monsoon from Chinese Cave Records: A Re-Assessment. The Holocene, 18, 861-866. https://doi.org/10.1177/0959683608095569

[33] Peng, Y., Xiao, J., Nakamura, T., Liu, B. and Inouchi, Y. (2005) Holocene East Asian Monsoonal Precipitation Pattern Revealed by Grain-Size Distribution of Core Sediments of Daihai Lake in Inner Mongolia of North-Central China. Earth and Planetary Science Letters, 233, 467-479. https://doi.org/10.1016/j.epsl.2005.02.022

[34] Xiao, J., Xu, Q., Nakamura, T., Yang, X., Liang, W. and Inouchi, Y. (2004) Holocene Vegetation Variation in the Daihai Lake Region of North-Central China: A Direct Indication of the Asian Monsoon Climatic History. Quaternary Science Reviews, 23, 1669-1679. https://doi.org/10.1016/j.quascirev.2004.01.005

[35] Djamali, M., Akhani, H., Andrieu-Ponel, V., et al. (2010) Indian Summer Monsoon Variations Could Have Affected the Early-Holocene Woodland Expansion in the Near East. The Holocene, 20, 813-820. http://whc.unesco.org/document/151856 https://doi.org/10.1177/0959683610362813

[36] Cheddadi, R. and Rossignol-Strick, M. (1995) Eastern Mediterranean Quaternary Paleoclimates from Pollen and Isotope Records of Marine Cores in the Nile Cone Area. Paleoceanography, 10, 291-300. https://doi.org/10.1029/94PA02672

[37] Viollet, P.L. (2010) Water Engineering and Management in the Early Bronze Age Civilizations. In: Cabrera, E., Ed., Water Engineering and Management through Time Learning from History, CRC Press, London. https://doi.org/10.1201/b10560

[38] http://whc.unesco.org/document/151856

[39] Spengler, R.N., et al. (2013) Archaeobotanical Results from Sarazm, Tajikistan, an Early Bronze Age Settlement on the Edge: Agriculture and Exchange. Journal of Environmental Archaeology, 18, 211-221. https://doi.org/10.1179/1749631413Y.0000000008

[40] Kak, S.C. (1989) Indus Writing. Mankind Quarterly, 30, 113.

[41] Sterling, S. (1999) Mortality Profiles as Indicators of Slowed Reproductive Rates: Evidence from Ancient Egypt. Journal of Anthropological Archaeology, 18, 319-343. https://doi.org/10.1006/jaar.1999.0344 
[42] Gibbons, A. (1993) How the Akkadian Empire Was Hung Out to Dry. Science, 261, 985-986. https://doi.org/10.1126/science.261.5124.985

[43] Linden, E. (2006) The Winds of Change: Climate, Weather, and the Destruction of Civilizations. Simon and Schuster, New York.

[44] Roland, T.P., Caseldine, C.J., Charman, D.J., Turney, C.S.M. and Amesbury, M.J. (2014) Was There a "4.2 ka Event" in Great Britain and Ireland? Evidence from the Peatland Record. Quaternary Science Reviews, 83, 11-27. https://doi.org/10.1016/j.quascirev.2013.10.024

[45] Bond, G., Showers, W., Cheseby, M., Lotti, R., Almasi, P., Priore, P. and Bonani, G.A. (1997) Pervasive Millennial-Scale Cycle in North Atlantic Holocene and Glacial Climates. Science, 278, 1257-1266. https://doi.org/10.1126/science.278.5341.1257

[46] Debret, M., Bout-Roumazeilles, V., Grousset, F., Desmet, M., McManus, J.F., Massei, N. and Trentesaux, A. (2007) The Origin of the 1500-Year Climate Cycles in Holocene North-Atlantic Records. Climate of the Past Discussions, 3, 679-692. https://doi.org/10.5194/cpd-3-679-2007

[47] Ning, L., Liu, J., Bradley, R.S. and Yan, M. (2019) Comparing the Spatial Patterns of Climate Change in the 9th and 5th Millennia BP from TRACE-21 Model Simulations. Climate of the Past, 15, 41-52. https://doi.org/10.5194/cp-15-41-2019

[48] Turney, C., Baillie, M., Clemens, S., Brown, D., Palmer, J., Pilcher, J., Reimer, P. and Leuschner, H.H. (2005) Testing Solar Forcing of Pervasive Holocene Climate Cycles. Journal of Quaternary Science, 20, 511-518. https://doi.org/10.1002/jqs.927

[49] Wanner, H., Beer, J., Bütikofer, J., Crowley, T.J., Cubasch, U., Flückiger, J., Goosse, H., Grosjean, M., Joos, F., Kaplan, J.O., Küttel, M., Müller, S.A., Prentice, I.C., Solomina, O., Stocker, T.F., Tarasov, P., Wagner, M. and Widmann, M. (2008) Midto Late-Holocene Climate Change: An Overview. Quaternary Science Reviews, 27, 1791-1828. https://doi.org/10.1016/j.quascirev.2008.06.013

[50] Sigl, M., Severi, M. and McConnell, J.R. (2008) A Role for Volcanoes in Causing the “4.2 Ka BP Event"? The 4.2 Ka BP Event. An International Workshop, Pisa, 10-12 January 2018.

[51] Chang, K.C. (1999) China on the Eve of the Historical Period. The Cambridge History of Ancient China: From the Origins of Civilization to, 221, 37-73. https://doi.org/10.1017/CHOL9780521470308.003

[52] An, Z., Porter, S.C., Kutzbach, J.E., Xihao, W., Suming, W., Xiaodong, L., Weijian, Z., et al. (2000) A Synchronous Holocene Optimum of the East Asian Monsoon. Quaternary Science Reviews, 19, 743-762. https://doi.org/10.1016/S0277-3791(99)00031-1

[53] Huguet, C., Kim, J.H., Sinninghe Damsté, J.S. and Schouten, S. (2006) Reconstruction of Sea Surface Temperature Variations in the Arabian Sea over the Last $23 \mathrm{kyr}$ Using Organic Proxies (TEX 86 and U 37 K'). Paleoceanography, 21, PA3003. https://doi.org/10.1029/2005PA001215

[54] Saher, M., Jung, S., Elderfield, H., Greaves, M. and Kroon, D. (2007) Sea Surface Temperatures of the Western Arabian Sea during the Last Deglaciation. Paleoceanography, 22, PA2208. https://doi.org/10.1029/2006PA001292

[55] Balaji, D., Bhushan, R. and Chamyal, L.S. (2018) Variations of the Somali Upwelling since $18.5 \mathrm{ka}$ BP and Its Relationship with Southwest Monsoon Rainfall. Climate of the Past, 14, 1331-1343. https://doi.org/10.5194/cp-14-1331-2018

[56] Wolff, C., Plessen, B., Dudashvilli, A.S., Breitenbach, S.F., Cheng, H., Edwards, L.R. 
and Strecker, M.R. (2017) Precipitation Evolution of Central Asia during the Last 5000 Years. The Holocene, 27, 142-154. https://doi.org/10.1177/0959683616652711

[57] Finkenbinder, M.S., Abbott, M.B. and Steinman, B.A. (2016) Holocene Climate Change in Newfoundland Reconstructed Using Oxygen Isotope Analysis of Lake Sediment Cores. Global and Planetary Change, 143, 251-261.

https://doi.org/10.1016/j.gloplacha.2016.06.014

[58] Jones, R. (1969) Fire-Stick Farming. Australian Natural History, 16, 224-228.

[59] Jones, R. (2012) Fire-Stick Farming. Fire Ecology, 8, 3-8. https://doi.org/10.1007/BF03400623

[60] Masse, B. (1998) Earth, Air, Fire, and Water: The Archaeology of Bronze Age Cosmic Catastrophes. In: Peiser, B.J., Palmer, T. and Bailey, M.E., Eds., Natural Catastrophes during Bronze Age Civilisations. Archaeological, Geological, Astronomical and Cultural Perspectives, Archaeo Press, Oxford, 78-79.

[61] Young Jr, T.C. (1973) Archeology: The Cambridge Ancient History. Volume One, Part Two: Early History of the Middle East. American Anthropologist, 75, 1110-1111. https://doi.org/10.1525/aa.1973.75.4.02a01360

[62] Makowski, M. TELL ARBID I. Clay Figurines. https://www.researchgate.net/profile/Maciej_Makowski2/publication/328383324 T ell Arbid I Clay figurines/links/5bc9c81b92851cae21b24691/Tell-Arbid-I-Clay-fig urines.pdf

[63] Owen, D.I. (1991) The First Equestrian: An Ur III Glyptic Scene. Acta Sumerologica, 13, 259-273.

[64] Fontes, J.C., Melieres, F., Gibert, E., Qing, L. and Gasse, F. (1993) Stable Isotope and Radiocarbon Balances of Two Tibetan Lakes (Sumxi Co, Longmu Co) from 13,000 BP. Quaternary Science Reviews, 12, 875-887. https://doi.org/10.1016/0277-3791(93)90026-I

[65] Anthony, D.W. (2007) The Horse the Wheel and Language. How Bronze-Age Riders from the Eurasian Steppes Shaped the Modern World. Princeton University Press, Princeton. https://doi.org/10.1515/9781400831104

[66] Huang, C.C., Pang, J., Zha, X., Su, H. and Jia, Y. (2011) Extraordinary Floods Related to the Climatic Event at 4200 a BP on the Qishuihe River, Middle Reaches of the Yellow River, China. Quaternary Science Reviews, 30, 460-468. https://doi.org/10.1016/j.quascirev.2010.12.007

[67] Wu, W.X. and Liu, T.S. (2004) Possible Role of the "Holocene Event 3" on the Collapse of Neolithic Cultures around the Central Plain of China. Quaternary International, 117, 153-166. https://doi.org/10.1016/S1040-6182(03)00125-3

[68] Street-Perrott, F.A. and Perrott, R.A. (1990) Abrupt Climate Fluctuations in the Tropics: The Influence of Atlantic Ocean Circulation. Nature, 343, 607-612. https://doi.org/10.1038/343607a0

[69] Thompson, L.G., Mosley-Thompson, E., Davis, M.E., Henderson, K.A., Brecher, H.H., Zagorodnov, V.S., Beer, J., et al. (2002) Kilimanjaro Ice Core Records: Evidence of Holocene Climate Change in Tropical Africa. Science, 298, 589-593. https://doi.org/10.1126/science.1073198

[70] Costa, K., Russell, J., Konecky, B. and Lamb, H. (2014) Isotopic Reconstruction of the African Humid Period and Congo Air Boundary Migration at Lake Tana, Ethiopia. Quaternary Science Reviews, 83, 58-67. https://doi.org/10.1016/j.quascirev.2013.10.031

[71] Yan, M. and Liu, J. (2019) Physical Processes of Cooling and Mega-Drought during 
the 4.2 ka BP Event: Results from TraCE-21ka Simulations. Climate of the Past, 15, 265-277. https://doi.org/10.5194/cp-15-265-2019

[72] Klus, A., Prange, M., Varma, V., Tremblay, L.B. and Schulz, M. (2018) Abrupt Cold Events in the North Atlantic Ocean in a Transient Holocene Simulation. Climate of the Past, 14, 1165-1178. https://doi.org/10.5194/cp-14-1165-2018

[73] Lin, J.-S., Wu, B. and Zhou, T.-J. (2016) Is the Interdecadal Circumglobal Teleconnection Pattern Excited by the Atlantic Multidecadal Oscillation? Atmospheric and Oceanic Science Letters, 9, 451-457. https://doi.org/10.1080/16742834.2016.1233800

[74] Stanley, J.D., Krom, M.D., Cliff, R.A. and Woodward, J.C. (2003) Short Contribution: Nile Flow Failure at the End of the Old Kingdom, Egypt: Strontium Isotopic and Petrologic Evidence. Geoarchaeology, 18, 395-402.

https://doi.org/10.1002/gea.10065

[75] Thompson, L.G., Mosley-Thompson, E. and Henderson, K.A. (2000) Ice-Core Palaeoclimate Records in Tropical South America since the Last Glacial Maximum. Journal of Quaternary Science: Published for the Quaternary Research Association, 15, 377-394. https://doi.org/10.1002/1099-1417(200005)15:4<377::AID-JQS542>3.0.CO;2-L

[76] Booth, R., Jackson, S., Forman, S., Kutzbach, J., Bettis, E., Kreigs, J. and Wright, D. (2005) A Severe Centennial-Scale Drought in Mid-Continental North America 4200 Years Ago and Apparent Global Linkages, The Holocene, 15, 321-328. https://doi.org/10.1191/0959683605hl825ft

[77] Aizen, E.M., Aizen, V.B., Takeuchi, N., Mayewski, P.A., Grigholm, B., Joswiak, D.R., Schwikowski, M., et al. (2016) Abrupt and Moderate Climate Changes in the Mid-Latitudes of Asia during the Holocene. Journal of Glaciology, 62, 411-439. https://doi.org/10.1017/jog.2016.34

[78] Catto, N. and Catto, G. (2004) Climate Change, Communities, and Civilizations: Driving Force, Supporting Player, or Background Noise? Quaternary International, 123-125, 7-10. https://doi.org/10.1016/j.quaint.2004.02.002

[79] Brooks, N. (2006) Cultural Responses to Aridity in the Middle Holocene and Increased Social Complexity. Quaternary International, 151, 29-49. https://doi.org/10.1016/j.quaint.2006.01.013

[80] Weiss, H., Courty, M.-A., Wetterstrom, W., Guichard, F., Senior, L., Meadow, R. and Curnow, A. (1993) The Genesis and Collapse of Third Millennium North Mesopotamian Civilization. Science, 261, 995-1004. https://doi.org/10.1126/science.261.5124.995

[81] Speiser, E.A. (1953) Early Law and Civilization. Canadian Bar Review, 31, 863.

[82] Speiser, E.A. (1963) Cuneiform Law and the History of Civilization. Proceedings of the American Philosophical Society, 107, 536-541.

[83] Jarrige, J.F. (2008) Mehrgarh Neolithic. Prāgdhārā, 18, 135-154.

[84] Miller, D. (1985) Ideology and the Harappan Civilization. Journal of Anthropological Archaeology, 4, 34-71. https://doi.org/10.1016/0278-4165(85)90013-3

[85] Mughal, D.M.R. (1990) Further Evidence of the Early Harappan Culture in the Greater Indus Valley: 1971-90. South Asian Studies, 6, 175-199. https://doi.org/10.1080/02666030.1990.9628411

[86] Possehl, G.L. (1997) The Transformation of the Indus Civilization. Journal of World Prehistory, 11, 425-472. https://doi.org/10.1007/BF02220556

[87] Mughal, D.M.R. (1990) The Decline of the Indus Civilization and the Late Harappan Period in the Indus Valley. Lahore Museum Bulletin, 3, 1-22. 
[88] Lemmen, C. and Khan, A. (2012) A Simulation of the Neolithic Transition in the Indus Valley. Climates, Landscapes, and Civilizations, 198, 107-114. https://doi.org/10.1029/2012GM001217

[89] Liu, C. and Ma, L.J. (1983) Interbasin Water Transfer in China. Geographical Review, 73, 253-270. https://doi.org/10.2307/214833

\section{List of Abbreviations}

C-Celsius degrees

aEAM-austral East African Monsoon

AHP-African Humid Period

ASM-African Summer Monsoon

bEAM-boreal East African Monsoon

$\mathrm{CO}_{2}$ - carbon dioxide

IOWP-Indian Ocean Warm Pool

ISM-Indian Summer Monsoon

ITCZ-Intertropical Convergence Zone

$\mathrm{K}-$ Kelvin degrees

ky-kiloyear (one thousand years)

MLW-Middle-Latitudes Westerlies

ppm-particles per million

SST-Sea Surface Temperature 